\title{
CONCEPTUAL FOUNDATIONS OF THE PROBLEM OF NATIONAL IDENTITY AWARENESS
}

\author{
Zafar Uzakovich Khayitov \\ Candidate of Philosophical Sciences, \\ Navoi State Pedagogical Institute, \\ Navoi city, Uzbekistan
}

Article DOI: https://doi.org/10.36713/epra3891

\begin{abstract}
Awareness of national identity is a complex, multifaceted spiritual state in the minds and beliefs of people, which impacts on all phenomena of social development. The level of national identity is an important factor for further development of the countries that have recently gained their independence. The essence of national identity phenomenon, its role in the existence of the nation, defining its status as sovereign entity, the role of the state factor in the system of national identity are analyzed via socio-philosophical analysis in the article.
\end{abstract}

KEY WORDS: ethnos, national values, Koran, national heritage, "title” nation, tolerance, political stability.

\section{DISCUSSION}

After the collapse of the Soviet Union in the late twentieth, in the former Soviet republics, including Central Asia, research on national consciousness, national identity, national ideology, national education became a crucial area of social and political sciences. The policy of the Soviet Union to form a "Single Soviet nation" based on the assimilation of all the peoples of the country to each other had always denied nationality in any field. The manifestation of national identity or the processes connected with national customs and traditions in the life of any nation, were considered as the appearance of "nationalism" or the factor that destroys the "single family" ideology. Since, understanding of national identity is related to a number of processes such as: the socio-political, the independent governance, the choice of models of development and ethno-political relations about the future of the nation.

Awareness of national identity cannot be analyzed in isolation from the concept of "nation", so that we will try to analyze the meaning of this concept. As "Nation" is a notion with a complex meaning, still in literature sources there is no consensus available to define it. However, there are aspects that generalize them. In particular, in the late 80 s of the twentieth century, we see that a number of scholars began to give priority to the factor of national identity.

The notions such as «миллат» (nation), «миллий» (nationa), «миллийлик» (nationality) entered the language of the peoples of Central Asia from the Arabic language in the $8^{\text {th }}$ century, during the conquest of Maverannahr by the Arab caliphate . The expression "мил" is used in the root of these notions. In Arabic language "мил" means "root", " core essence", "basis". The concept of "nation"(миллат) is widely used and has several meanings: 1) religion, religious community; 2) the ummah, the community of people with common religious beliefs; 3) also means people, nation. [1, p.160.]

It is obvious that the concept of 'nation' which has been used in Arabic is broader and much deeper according to its dictionary meaning, than it is understood today.

The religious and mythological views on the origin of nations are of great importance and noteworthy. According to the Bible, God in a rage sends a flood on the people, and the whole Earth is flooded. As a result, all living beings on Earth are perished. In the flood only prophet Noah with his family and a pair of all the animals survived in Noah`s Ark. After some time, the flood stops and life on earth begins again. All the people who later appeared on Earth were descended from the offspring and descendants of Noah. The animals are the descendants of the animals that survived in Noah's Ark. [2, p.9.]

According to another biblical narration, people lived in one place and when their number increased, they became too proud and lost fear towards the God, as a result they initiated to construct a high seven-story tower in Babylon 
(Babylon). This makes the God angry, he sends the people who once spoke the same language all over the Earth, changing their languages into different ones. [3, p.13.]

As it is given in Surah al-Baqara, Yunus, Hud, and Nahl of Holy Koran, the God created all human beings from a single father and mother. It means that originally all people were of the same nation and then split up into various nations. The Koran urges every believer not to renounce his own nation and become another nation: «And do not be like her who unravels her yarn, breaking it into pieces, after she has spun it strongly. Nor use your oaths as means of deception among you, because one community is more prosperous than another. God is testing you thereby. On the Day of Resurrection, $\mathrm{He}$ will make clear to you everything you had disputed about». [4, p.138.]

Hence, in religious books, believers of one religion are defined as the offspring of a single "nation." On the basis of such a doctrine, the idea and belief in it are accepted as the base. Of course, such views became the basis for studying the concept from secular science view point. Although the definition of "nation" from a religious point of view, in most cases, had a positive effect on the people of the same religion and ideology, but over years it has become a means of pitting people of different religions against each other.

According to modern socio-political conceptual views, the phenomenon of national identity awareness is classified on the basis of philosophical, historical and psychological approaches, regarding the human being as a creature that is capable to distinguish his own "I" from the others in his surroundings. From the distant past, tribes and ethnic groups have been interacting with each other, and as a result, they have exchanged and learned cultural, social, scientific, and economic experience from each other. Since then, people had an idea not only about other nations, but also about their own differences from them. These were the first signs of realizing self-identity and selfrealization. From this point of view it could be said that self-awareness, perception and distinction of it are the prelude to the understanding of national identity.

Understanding of national identity is a complex and multifaceted concept. Therefore, there is no consensus in the literature sources available to define it precisely. It is noteworthy that in the late twentieth century, in defining this concept, scientists began to draw attention to the need for the existence of a nation-state in the system of the concept of national identity. [5, p.51-52; 6, p.105.].

In order to understand the national identity, there must be a certain national statehood. It is known that people of different nationalities and ethnic groups living in other countries consider as their motherland the state which is named after their own nation, including its territories. In addition, the fact that a number of nations around the World are actively working on establishing their own nationstates, confirms that the state has a priority in the notion of "national identity". At the same time, giving priority to the factor of national statehood in the system of "national identity" could never be a basis for "denying" the place and role of spiritual factors in the broadest sense.

At the same time, the nation-state is an important condition for the existence and development of the nation, because the sociopolitical characteristics associated with the state are crucial in the formation of the nation. Precisely these elements unite all others, accelerate and ensure their rapprochement, collaboration, and aspiration for commonality. [7, p.8.] This could be the only way to create conditions for the comprehensive development of the nation and realization of its potential. In our view, such an approach does not deny economic, geographical, cultural and spiritual factors, instead it is further accentuating to base on their historical background.

Simultaneously, any system of statehood could be stable and viable only if it is built on a national basis and meets the spiritual needs of the indigenous population. The German philosopher G. Gegel points out that the connection between selfawareness and the state factor is twofold, "The main purpose of the people (nation) is to establish and maintain themselves as a state. The people (nation) do not have any history without the state .. [ $\left.{ }^{8}, \mathrm{p} .329.\right]$ Thus, from his point of view, the people can constitute their own independent state only when they consider themselves the people of the same history, origin and place. Hegel sees the state as the basis of people's life, it is art, morality, religion, science, and the spirit of the people that surrounds them.

The example of European countries could be taken for granted in the formation of the nation under the influence of nation-states, unification of nations and the development of self-awareness.

Here, during the transition from medieval society to the new industrial society, or more precisely in the period of transition to the capitalist system, political centralization was expressed through the structure of nation-states and played an important role in accelerating economic centralization, the emergence of a single literary language based on the combination of different dialects. Hence, they contributed to the development of national identity and unification of the nation through the legal management of social life, education system, specific media in their territories.

At the same time, economic and political centralization are closely connected and interdependent on each other. The process of 
unification and governing of the nation as a single state is accelerated in the territory inhabited by the people with similar languages, cultures and origin. That is, the formation of national statehood creates a new source and mechanisms of consolidation, which regulates complex social relations and coordinates the understanding and feeling of cultural, social and political unity of all citizens of the country, regardless of ethnicity and class.

This example is especially relevant for the largest countries in Europe, such as England and France. Thus, such specific aspects of the historical development of each region are reflected in the awareness of the national identity of peoples. The country, with its own territorial unity and rules of socio-economic life, is directly interested in the development of national customs and traditions. [9, p.22.]

In our opinion, due to this, the formation of nation-states and nations in Europe was relatively smooth and stable.

Turkish writer Ziya Kokalp praises the level of self-awareness of the peoples of Europe as a nation and says:

"History and the testimonies of the present show us that there is no nation left in Europe today that does not have a national conscience. Accordingly, no country in Europe has the opportunity to establish a colony. " $[10$, p.60.]

However, recognizing the variance in the level of accepting of national identity in different peoples should not be understood as distinguishing peoples from one another according to their natural, spiritual and social development opportunities. In other words, the level of consciousness, intellectual and practical development opportunities of peoples does not depend on their race, belief or nationality. Concurrently, the uniqueness of the historical development of nations, the gained experience, the way of living and the conditions within it will inevitably affect the level of being aware of national identity.

Indeed, most of the nation-centered states in Europe were formed in the 15th and 16th centuries. The main part of the population of these states consisted of representatives of one nation, and their territories also took on an almost present appearance at that time. Accordingly, the perceptions of the population of these countries about trade, economic, cultural relations, the state, the nation have been unchanged for centuries.

On the other hand, in Central Asia the states established at different times and their internal administrative structures were grounded on territorial commonality rather than national unity. (For example, Bukhara Emirate, Khiva Khanate, Kokand Khanate). All of these states were multi-ethnic, and historically indigenous peoples of these states lived in a scattered way. For a long time, the unifying factor in the population of these states was territorial or religious affiliation. After the collapse of the Russian Empire and the establishment of the Soviet Union, the "national-territorial delimitation" implemented by the Center for the peoples of Central Asia in late 1924 and the new "national statehood" introduced subtle alterations in their further development. As a result of the inclusion of the republics of Bukhara and Khorezm in the national territorial boundaries, their division and incorporation into the former USSR, these two ancient states of Central Asia were completely eliminated from the political map of the World. Consequently, the millennial history of Central Asian statehood was undermined.

Until the "national-state delimitation" in the late 1924, despite the changing regions, the environment that formed the basis of Central Asian statehood - the specific economic, domestic, religious, spiritual and cultural, common life remained unchanged. Each ethnic group had its own specific territory, which would continue to be an integral, invariably equal part of the commonality. With the formation of the allied republics, there was introduced the discrimination and stratification of nations. This difference was evident not only in the status of their formation, but also in the name of the ethnos and the "minorities".

Hence, although some of the nations lived on the land of their ancestors according to the official definition they were considered as a "minority nation". This affected their consciousness and selfawareness. In addition, this situation undoubtedly had a negative impact on ethno-national processes within the communities. The complexity of the situation was exacerbated by the problem of ethnos, although the new national structures comprised the bulk of the "title" nation, due to scattered location of people it was also considered as a multi-ethnic society, with a certain proportion of similar ethnic groups. [11, p.301.]

Any attempt of these similar ethnic groups to unite into a single state could lead to sharp conflicts. In general, the Bolshevik`s project of the national-territorial delimitation meant putting a timeconsuming explosive needle under the future interethnic relationship among the peoples of Central Asia, which would inevitably explode in emergencies and provoke various conflicts.

It is not a secret that these measures were aimed at extinguishing or weakening the spirit and the sense of national identity of the peoples of Central Asia, which was the source of their power. Human history and modern civilization show that society and human development, like natural processes, require continuous and logical, natural and legitimate evolution. 


\section{CONCLUSION}

From the above mentioned, it can be concluded that the understanding of national identity is belonging to a particular ethnic group, nation-state, having the sense of duty and responsibility to it. Moreover it is a general theoretical and practical approach to the protection and development of material and spiritual values, interests, national unity and solidarity. The awareness of national identity does not arise suddenly or by chance, it cannot be forcibly assimilated into the minds of the people and the life of society. It is a process that is formed during the entire historical development of the nation and constantly evolving and improving due to the opportunities and needs of certain conditions. The extent of this feeling and its power of influence depend on the historical background of the nation and perhaps on level of national identity awareness. Therefore, the scientific analysis of the problem of self-awareness requires a holistic study of all periods and factors of historical development.

\section{REFERENCES}

1. Ислом энииклопедияси. -Ташкент, “Ўзбекистон миллий энщииклопедияси", 2004. $-p .160$.

2. Bible. The Old Testament. Book of Genesis. "Российское Библейское Общество”, -M., 1997. Chap. 6-7. -p. 911.

3. The Bible. The Old Testament. Book of Genesis. "Российское Библейское Общество”, -М., 1997. Chap. 11. -p.13.

4. The Quran. Surah Al Nahl, 92-Ayah. (Translated to English by Talal Itani). Dallas, 2012. -p.138.

5. Атамуратов С. Национальная культура и начиональное самосознание в прочесс обновления общества. (сочиальнофилософский аспект). Дисс.на.соиск.учен.степ.док.философ. наук. -Ташкент, 1992. - р.50-51.

6. Яблокова Е.А. Субъекты общественной психологии. Теоретическая $и$ прикладная социология. -М., "Мысльь", 1998. - p.105.

7. Кўчқ̧оров В. Маънавият ва миллий узликни англаш.-Ташкент, “Академия”, 2008. - p.8.

8. Гегель Г. Сочинения. Т.З. Философия духа. -М., "Государственное издательство политичской литературь", 1956. -р.329.

9. Руткевич М.Н.Теория нации: вопросы философии // Вопросы философии. -М., 1999.-№5. - p.22.

10. Зиё Кўкалп. Туркчилик асослари. Ташкент, "Чўлпон”, 1994, -р.60.

11. Ўзбекистон Совет мустамлакачилиги даврида // Ўзбекистоннинг Янги тарихи. 2-том. -Ташкент, 2000, «Шарж̧». - p.301. 